\title{
Blood AST and ALT profile of Sumba Ongole cattle
}

\author{
Cynthia Dewi Gaina ${ }^{1 *}$, Maxs U.E. Sanam ${ }^{1}$, Wilmientje M.M. Nalley ${ }^{2}$, \\ Imanuel Benu' ${ }^{2}$ Agus Saputra ${ }^{1}$ \\ ${ }^{1}$ Faculty of Veterinary Medicine, Nusa Cendana University \\ ${ }^{2}$ Faculty of Animal Science, Nusa Cendana University
}

\begin{abstract}
A study was carried out in one of Indonesia native cattle, Sumba Ongole (SO) Cattle for determination of statuses of various biochemical parameters, aspartate aminotransferase (AST or SGOT) and alanine aminotransferase (ALT or SGPT). Apparently blood from randomly selected cattle $(n=36)$ were collected aseptically. Biochemical analysis of AST and ALT was performed on UPT Laboratorium Kesehatan, Kupang, Nusa Tenggara Timur. The results showed that the variations of parameters were not significant $(\mathrm{p}>0.05)$ between male and female SO cattle. The AST/SGOT $(142.56 \pm 20.55$ U/l) was slightly higher in female compared with the male $(137.00 \pm 16.24 \mathrm{U} / \mathrm{l})$, while level of ALT/SGPT were $46.44 \pm 10.99 \mathrm{U} / \mathrm{l}$ in male and 46.41 $\pm 10.23 \mathrm{U} / \mathrm{l}$ in female. Although, the result was not significant ( $\mathrm{p}>0.05$ ), level of AST and ALT in SO cattle was higher compared to standard which is 60-125 U/l for AST and 6.9-35 U/l for ALT. Results showed possibility of seasonal effect on AST and ALT level in male and female SO cattle.
\end{abstract}

Keywords:

AST, ALT, Sumba Ongole, cattle

\section{- INTRODUCTION}

The Sumba Ongole (SO) cattle is one of the Indonesian native cattle that plays an important role in nutrition directly through the consumption of its products by livestock owners and their families; and indirectly through the sale of animals and animal products as a source of income. Recently, farmers in East Sumba select the SO cattle based on its performance (Said et al. 2016). However, almost no reports about blood biochemical profile of the SO cattle. Determination of normal values for blood biochemical values is important for the clinical interpretation of laboratory data. These indices may vary depending on factors such as sex, age, weather, stress, season, nutrition and physiological status of the animal as it measure metabolic and health status of the animal (Kaneko et al. 1997; Osman and AlBusadah 2003).

One of the most common blood tests is a liver blood test, which assesses liver functions or liver injury. A basic liver blood test determines the level of certain enzymes (proteins) in the blood, which regulate the functioning of important chemical reactions in the body. Among the most sensitive and widely used liver enzymes are the aminotransferases. These include aspartate aminotransferase (AST or SGOT) and alanine aminotransferase (ALT or SGPT). The test of metabolic profiles by analyzing biochemical parameters in the blood of cows made by Payne and Payne (1987) is a significant contribution to veterinary medicine. Biochemical parameters are also responsible for various body functions and its deficiency result in impairment of functions induces structural and physiological abnormalities (McDowell 1992).

As a consequence, the biochemical values during different physiological conditions should be determined for the diagnosis of various pathological and metabolic disorders, which can harmfully affect the productive and reproductive performance of cattle, resulting in great economic losses to beef farmers (Dutta et al. 1988). Therefore, this aim of this study was to identify the biochemical profiles, AST and ALT of Sumba Ongole cattle in both male and female cattle herded in East Sumba, Nusa Tenggara Timur.

\section{n MATERIAL AND METHOD}

Sample collection: The study was carried out in Sumba Island Regency, NTT where cattle $(n=36)$ were reared under free-range condition. After proper investigation, the sampling was performed and approximately 3-5 ml blood samples were collected from jugular vein aseptically. Collected blood samples were kept in vacutainer (without anticoagulant). Samples collection was carried out in accordance with the guidelines laid down by the Animal Ethics Committees in Nusa Cendana University with the series number KEH/FKH/NEPH/2019/003.

Received: 20-01-2020 | Revised: 25-02-2020 | Accepted: 27-02-2020 (c) 2020 CC-BY-SA. This is an Open Access article that is distributed under the terms of Creative Commons Attribution ShareAlike 4.0 International License (https://creativecommons.org/licenses/by-sa/4.0/). 
Table 1. Profile serum ALT and AST of Sumba Ongole cattle

\begin{tabular}{|c|c|c|c|c|c|}
\hline \multirow{3}{*}{ Parameter } & \multicolumn{4}{|c|}{ Category } & \multirow{3}{*}{$P$ value } \\
\hline & \multicolumn{2}{|c|}{ Male $(n=18)$} & \multicolumn{2}{|c|}{ Female $(n=18)$} & \\
\hline & Mean \pm SEM & $95 \% \mathrm{CI}$ & Mean \pm SEM & $95 \% \mathrm{CI}$ & \\
\hline AST (U/l) & $137.00 \pm 16.24$ & $128.92-148.08$ & $142.56 \pm 20.55$ & $132.34-152.77$ & 0.551 \\
\hline ALT (U/l) & $46.44 \pm 10.99$ & $40.98-51.91$ & $46.41 \pm 10.23$ & $41.53-51.70$ & 0.525 \\
\hline
\end{tabular}

Laboratory analysis of sample: Serum was placed in normal temperature and it was evaluated for AST and ALT by an automated biochemical analyzer in UPT Laboratorium Kesehatan, Kupang, Nusa Tenggara Timur.

Statistical analysis: Obtained laboratory data was stored in Microsoft Excell-2007 and imported to the SPSS for analysis. Descriptive statistics analysis was done to measure the mean, SEM, 95\% confidence interval (CI) and $\mathrm{P}$ value of different parameters. The two sample paired t-test was done to compare the sex variation and $\mathrm{P}$ value $(\mathrm{p}<0.05)$ was considered for level of significance.

\section{- RESULTS AND DISCUSSION}

There was no significant variation $(\mathrm{p}>0.05)$ observed in AST and ALT (Table 1). This study showed that AST (142.56 $\pm 20.55 \mathrm{U} / \mathrm{l})$ was slightly higher in female compared to the male $(137.00 \pm 16.24 \mathrm{U} / \mathrm{l})$, while level of ALT/SGPT were $46.44 \pm 10.99 \mathrm{U} / \mathrm{l}$ in male and $46.41 \pm 10.23 \mathrm{U} / \mathrm{l}$ in female. Although, the result was not significant $(p>0.05)$, level of AST and ALT in SO cattle was higher compared to standard (Bedenicki et al. 2014). Standard level of AST and ALT is 60-125 U/l and 6.9-35 U/1, respectively. The level of enzymes in the blood regulates metabolic activity in the animal could be exposed to stress (Gupta et al. 2013).

This study has shown that a tendency of an increasing level of AST and ALT in male and female group tends to be affected by stress during summer season in Sumba Island. It has been reported that goat had higher level of both AST and ALT during summer (Nazifi et al. 2003), similarly with dairy cows with higher level of both AST and ALT during summer compare to winter (Alameen et al. 2012). Although ALT was not significantly different between male and female, but the increasing of ALT may be due to increase of gluconeogenesis (Koubkova et al. 2002) or some damaged effect of heat stress on liver activity (Marai et al. 1997). Thus, during diagnostic procedure it is very useful to compare the values obtained from ill animals with normal values of healthy animal.

\section{- CONCLUSION}

Biochemical tests of blood serum showed a not significant result for AST and ALT in both female and male group. Results indicate that a slightly higher level of AST and ALT tends to be affected by seasonal factor.

\section{- AUTHOR INFORMATION}

Corresponding Author

*CDG: cynthia.gaina@staf.undana.ac.id
Department of Veterinary Clinic, Reproduction, Pathology, and Nutrition, Faculty of Veterinary Medicine, Nusa Cendana University, Indonesia

\section{aCKNOWLEDGEMENT}

This study is supported by USAID through Sustainable Higher Education Research Alliances (SHERA) Program - Center for Collaborative Research Animal Biotechnology and Coral Reef Fisheries (CCR ANBIOCORE) and the Department of Animal Husbandry in East Sumba Regency for providing technical support to conduct the study.

\section{- REFERENCES}

Alameen AO, Abdelatif AM. 2012. Metabolic and endocrine responses of crossbred dairy cows in relation to pregnancy and season under tropical conditions. American-Eurasian Journal of Agricoltural \& Environmental Science. 12(8):1065-1074.

Bedenicki M, Potocnjak D, Harapin I, Radisic B, Samardzija M, Kreszinger M, Zubcic D, Djuricic D, Bedrica L. 2014. Haematological and biochemical parameters in the blood of an indigenous Croatian breed-Istrian cattle. Archives Animal Breeding. 57(1):1-7.

Dutta JC, Baruah RN, Dutta L, Talukdar SC. 1988. Blood biochemicalstudies in anestrous and normal cyclic cattle. Indian Veterinary Journal. 65(3):239-241.

Gupta AR, Dey S, Swarup D, Saini M, Saxena A, Dan A. 2013. Ameliorative effect of Tamarindus indica L. on biochemical parameters of serum and urine in cattle from fluoride endemic area. Veterinarski arhiv. 83(5):487-496.

Kaneko JJ, Harvey JW, Bruss ML. 1997. Clinical Biochemistry of Domestic Animals, Academic Press 5th Ed. San Diego.

Koubkova M, Knizkova L, Kunc P, Hartlova H, Flusser J, Dolezal O. 2002. Influence of high environmental temperatures and evaporative cooling on some physiological, hematological and biochemical parameters in high-yielding dairy cows. Czech Journal of Animal Science. 47(8):309-318.

Marai IF, Daader AH, Abd-El-Samee AM, Ibrahim H. 1997. Winter and summer effects and their amelioration on lactating Friesian and Holstein cows maintained under Egyptian conditions. In International Conference on Animal, Poultry, Rabbit Production and Health, Cairo (Egypt), 2-4 Sep 1997.

McDowell LR. 1992. Minerals in animal and human nutrition. London, Academic pp. 265-293.

Nazifi S, Saeb M, Rowghani E, Kaveh K. 2003. The influences of thermal stress on serum biochemical parameters of Iranian fat-tailed sheep and their correlation with triiodothyronine ( $\mathrm{T} 3$ ), thyroxine ( $\mathrm{T}$ 4 ) and cortisol concentrations. Comparative Clinical Pathology. 12(3):135-139.

Osman TE, Al-Busadah KA. 2003. Normal concentrations of twenty serum biochemical parameters of she-camels, cows and ewes in Saudi Arabia. Pakistan Journal of Biological Sciences. 6(14):1253-1256.

Payne JM, Payne S. 1987. The metabolic profile test. Oxford University Press.

Said S, Agung PP, Putra WP, Anwar S, Wulandari AS, Sudiro A. 2016. Selection of Sumba Ongole (SO) cattle based on breeding value and performance test. Journal of Indonesian Tropical Animal Agriculture. 41(4):175-187. 